\title{
STUDY EFFECTS OF VARIOUS DOSAGE OF POLYPROPYLENE FIBER AND DIFFERENT DOSAGE OF STYRENE BUTADIENE RUBBER ON COMPRESSIVE STRENGTH OF POLYMER MODIFIED MORTAR
}

\author{
Kamlesh S.Dalal $^{1}$, C.D.Modhera ${ }^{2}$, S. A Vasanwala ${ }^{3}$ \\ ${ }^{1}$ Research Scholar, ${ }^{2,3}$ Professor, Department of Applied Mechanics, \\ S V National Institute of Technology, Ichchhanath, Surat-395007, India, dalalks@gmail.com
}

\begin{abstract}
The perception of use polymer modified mortar is well known in repair engineering, which includes various \% of styrene butadiene rubber, acrylic and other materials. The worry should not be solely with repair materials but with the uses to which they are being to put and lack of awarenessof material during application, Material (say mortar) and end product(composite repair)will not perform and then less durable. In this paper, effects of 10\%, 15\% and 20\% of SBR in polymer modified mortar as well as polypropylene fibre in the range of $0 \%$ to $1 \%$ on compressive strength has been studied.
\end{abstract}

Key words: Individual compressive strength, polypropylene fibre,SBRpolymer modified mortar.

\section{INTRODUCTION}

Various studies prove and alarming about deterioration and distress plenty of existing concrete structures worldwide in third millennium ${ }^{[15][17]}$

Simultaneously, it must also be documented that many repaired concrete structures are severely deteriorated only after a few years having been repaired. Each country is facing this major problem: How to repair, rehabilitate and protect the existing stock of concrete structures in order to prolong their service life. All over the world, concrete has been well and truly used all the way throughout the centuries. In recent years the image of concrete has been shaken by durability problems, by often poor performance, and most of all, by concrete repair failures. The repair failures and endless "repair of repairs" made a considerable contribution to the current perceptions of concrete. The poor durability performance of many concrete structures is causing disruption and expenditure on remedial works which owners and society cannot afford and do not wish to see repeated. ${ }^{[16][13]}$

Various polymers like SBRtrim down the rate of water evaporation, allow the crystal structure to keep growing and building strength during these important early curing stages. This reduced water evaporation is especially important in thin applications, where the surface area for evaporation is high, relative to the volume of the mortar. It is necessary and preferable to add polypropylene fibre to resist the adverse effects of volume changes in polymer modified mortar ${ }^{[8][9][34]}$

\section{REASEARCH SIGNIFICANCE}

Cracking of the repair material is cause of repair failure and lead to most serious deterioration in concrete and other cement-based materials,. When large, visible cracks become interconnected with already exist micro-cracks of aggregate mortar and reinforcement mortar, the network of cracks facilitates the transport of aggressive ions and gases to the embed reinforcement, leading to untimely corrosion and deterioration. The structure of cement-based materials is complex. It is a heterogeneous mixture of different components with widely changeable characteristics and properties. It is a physico-chemical component consisting of hydratedcementitious materials, aggregates, additives and admixtures. With composite systems, such as repair, the complex link between phenomena, theory and expressive parameters encourages a more detailed study of the materials based on the properties of the component phases and how these interact. Indisputable progress has been made in the field of repair materials. But the material that has the required properties for a particular application is only one stage in the multipart system that makes up the totality of concrete repair. The problem of durable concrete repair is not simple than it appears at first sight due to notmatch with substrate. So, if material does not perform, we cannot say "high-performance material". In additionto that before we continue to talk about the subject of repair materials astutely, we have to reorganizeour thoughts and ideas. ${ }^{[7][49][51]}$

The data presented in this paper is part of our research work; wepresented effects of $0 \%$ to $1 \%$ of Polypropylene fibre and $10 \%, 15 \%$ and $20 \%$ of SBR in PMM's compressive strength. 


\section{THE METHODOLOGY AND}

\section{INVESTIGATIONS}

\subsection{Experimental Programme}

We studied effect of various dosages of polypropylene fibre and SBR on compressive strength of polymer modified mortar specimens.

\subsubsection{Constituent Materials}

\section{Properties of Cement}

\begin{tabular}{|l|l|l|}
\hline Sr. No. & Test & Results \\
\hline 1. & Fineness (By Blaine's Method) & $3369 \mathrm{~cm} 2 / \mathrm{gm}$ \\
\hline 2. & $\begin{array}{l}\text { Setting Time } \\
\text { Initial } \\
\text { Final }\end{array}$ & $\begin{array}{l}90 \text { Minutes } \\
230 \text { Minutes }\end{array}$ \\
\hline \multirow{2}{*}{3.} & \begin{tabular}{l} 
Compressive Strength $(\mathrm{kg} / \mathrm{cm} 2)$ \\
3 days \\
\cline { 2 - 3 }
\end{tabular} & 172 \\
\cline { 3 - 3 } & 28 days & 320 \\
\cline { 3 - 3 } 2. & $\begin{array}{l}\text { Soundness (Le Chatterley's } \\
\text { Method) Expansion between two } \\
\text { joints }\end{array}$ & $1.2 \mathrm{~mm}$ \\
\hline 5. & Normal Consistency & $29.5 \%$ \\
\hline
\end{tabular}

Properties of fine Aggregate

\begin{tabular}{|l|l|}
\hline Properties & $\begin{array}{l}\text { Fine } \\
\text { Aggregate }\end{array}$ \\
\hline $\begin{array}{l}\text { Fineness } \\
\text { Modulus }\end{array}$ & 3.11 \\
\hline $\begin{array}{l}\text { Specific } \\
\text { Gravity }\end{array}$ & 2.78 \\
\hline $\begin{array}{l}\text { Bulk Density } \\
(\mathrm{kg} / \mathrm{m} 3)\end{array}$ & 1886.0 \\
\hline
\end{tabular}

\section{Sieve Analyses of Aggregates}

\begin{tabular}{|l|l|l|}
\hline \multirow{2}{*}{$\begin{array}{l}\text { IS: Sieve } \\
\text { designation }\end{array}$} & $\begin{array}{l}\text { Fine Aggregate } \\
\text { (Sand ) }\end{array}$ \\
\cline { 2 - 3 } & Cum \% of retained & \multicolumn{2}{|l}{} \\
\hline $40 \mathrm{~mm}$ & - & - \\
\hline $25 \mathrm{~mm}$ & - & - \\
\hline $20 \mathrm{~mm}$ & - & - \\
\hline $10 \mathrm{~mm}$ & - & - \\
\hline $4.75 \mathrm{~mm}$ & 5.0 & 95.0 \\
\hline $2.36 \mathrm{~mm}$ & 16.0 & 84.0 \\
\hline $1.18 \mathrm{~mm}$ & 40.2 & 59.8 \\
\hline 600 Micron & 58.2 & 41.8 \\
\hline 300 Micron & 92.2 & 7.80 \\
\hline 150 Micron & 99.2 & 0.80 \\
\hline & & \\
\hline
\end{tabular}

Water: The drinkable water was used during experimental program

\section{Polypropylene fibre:}

- $6 \mathrm{~mm}$ polypropylene fibres used for experimental work.

- Fine fibrillated harbourite fibre conform ASTMC1116 \& ASTMC1028

\section{SBR (styrene butadiene rubber)}

It is a polymer based on styrene butadiene rubber, we can use it for structural rehabilitations, waterproofing treatment, floor screeds, \& topping and concrete repairs.

Advantages of SBR are excellent adhesive to reinforcement \& concrete, increased flexural strength, increased tensile strength; we get compressive strength comparable to that of concrete, reduced shrinkage, reduced water permeability, improved chemical resistance.

Typical properties of SBR \& modified mortar and typical values are Ph: 9.5 Specific gravity: 1.01 Freeze thaw stability: With stands at least 5 freeze thaw cycles, but storage in covered areas, Stabilization: Non-Ionic, Anti Oxidant, Bactericide, Antifoam, Yield is $0.1 \mathrm{~m}$ above mix $10 \mathrm{~m}$ area at $10 \mathrm{~mm}$ thickness.

Technical data

1) Color: Bluish white/milky liquid polymer.

2) Solid Content: 36\% (ASTM D 1417-10)

3) Specific Gravity: 1.02

4) Bond Strength: 2 times more than normal cement slurry coating. 


\section{Mix Proportions and Experimental Factors:}

We casted and tested following mixes for our experimental study:

Table1: Various mixes

\begin{tabular}{|c|c|c|c|}
\hline $\begin{array}{c}\text { Description } \\
\text { of Specimen } \\
\text { For Mortar } \\
(1: 2)\end{array}$ & $\%$ SBR & $\begin{array}{c}\text { \%Dosa } \\
\text { ge of } \\
\text { Fibre }\end{array}$ & Nos.of specimens \\
\hline \multirow{15}{*}{$\begin{array}{c}\text { CUBE } \\
(70.6 \mathrm{mmx} 7 \\
0.6 \mathrm{mmx} 70 . \\
6 \mathrm{~mm})\end{array}$} & 10 & 0 & \multirow{15}{*}{$\begin{array}{c}\text { Each mix have cast } \\
\text { 6nos.of specimens = } \\
90 \text { Nos. }\end{array}$} \\
\hline & 15 & 0 & \\
\hline & 20 & 0 & \\
\hline & 10 & 0.25 & \\
\hline & 15 & 0.25 & \\
\hline & 20 & 0.25 & \\
\hline & 10 & 0.5 & \\
\hline & 15 & 0.5 & \\
\hline & 20 & 0.5 & \\
\hline & 10 & 0.75 & \\
\hline & 15 & 0.75 & \\
\hline & 20 & 0.75 & \\
\hline & 10 & 1.0 & \\
\hline & 15 & 1.0 & \\
\hline & 20 & 1.0 & \\
\hline
\end{tabular}

15 different mixes were prepared with cement sand mortar (1:2) using SBR at varying percentage of 10, 15, and 20by weight of cement and polypropylene fibre $\%$ of $0.0,0.25$, $0.50,0.75$, and 1.00 also by weight of cement and as per Table 1.
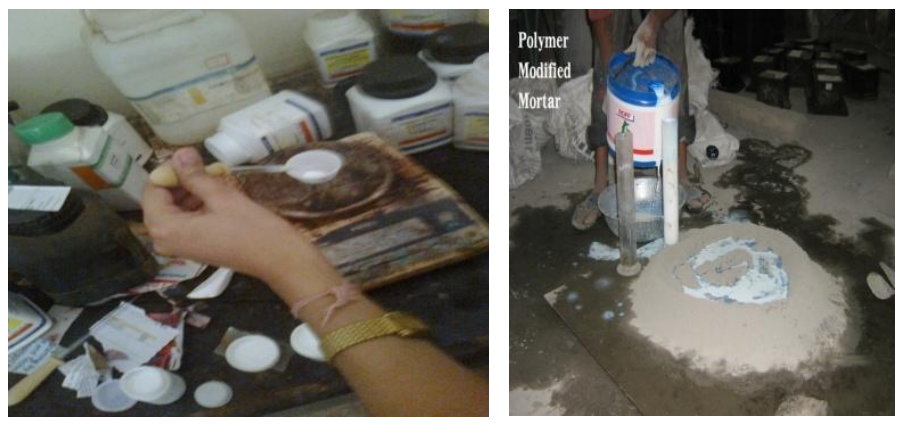

Fig.1Photographs of Testing and mixing Polymer Modified Mortar

Test Results: Test results are presented graphically and in tabular form.
Table.2 Variation in compressive strength with various $\%$ of fibre in PMM (SBR 10\%)

\begin{tabular}{|c|c|c|c|c|c|}
\hline \multicolumn{6}{|l|}{ PMM SBR $10 \%$} \\
\hline$\%$ fibre & 0 & 0.25 & 0.5 & 0.75 & 1 \\
\hline $\begin{array}{l}(7-\text { DAYS }) \\
\text { Avg. Comp. } \\
\text { Strength } \\
(\mathrm{MPa})\end{array}$ & 24.44 & 25.27 & 24.07 & 23.69 & 23.47 \\
\hline $\begin{array}{l}\text { (28 } \\
\text { DAYS)Avg. } \\
\text { Comp. } \\
\text { Strength } \\
\text { (MPa) }\end{array}$ & 30.64 & 31.67 & 30.17 & 29.70 & 29.42 \\
\hline
\end{tabular}

Table. 3 Variation in compressive strength with various $\%$ of fibre in PMM (SBR 15\%)

\begin{tabular}{|l|l|l|l|l|l|}
\hline \multicolumn{2}{|l|}{ PMM SBR 15\% } \\
\hline \% fibre & 0 & 0.25 & 0.5 & 0.75 & 1 \\
\hline $\begin{array}{l}\text { (7 - DAYS) Avg. } \\
\text { Comp. Strength } \\
\text { (MPa) }\end{array}$ & 29.03 & 29.7 & 30.24 & 28.47 & 28.2 \\
\hline $\begin{array}{l}\text { (28 } \\
\text { DAYS)Avg. } \\
\text { Comp. Strength } \\
\text { (MPa) }\end{array}$ & & & & & \\
\hline
\end{tabular}

Table.4 Variation in compressive strength with various $\%$ of fibre in PMM (SBR 20\%)

\begin{tabular}{|l|l|l|l|l|l|}
\hline \multicolumn{6}{|l|}{ PMM SBR 20\% } \\
\hline \% fibre & 0 & 0.25 & 0.5 & 0.75 & 1 \\
\hline $\begin{array}{l}\text { (7 - DAYS) } \\
\text { Avg. Comp. }\end{array}$ & & & & & \\
$\begin{array}{l}\text { Strength } \\
\text { (MPa) }\end{array}$ & 32.33 & 33.07 & 33.47 & 31.63 & 31.33 \\
\hline $\begin{array}{l}\text { (28 - } \\
\text { DAYS)Avg. }\end{array}$ & & & & & \\
$\begin{array}{l}\text { Comp. } \\
\text { Strength } \\
\text { (MPa) }\end{array}$ & 36.45 & 37.28 & 37.73 & 35.66 & 35.33 \\
\hline
\end{tabular}




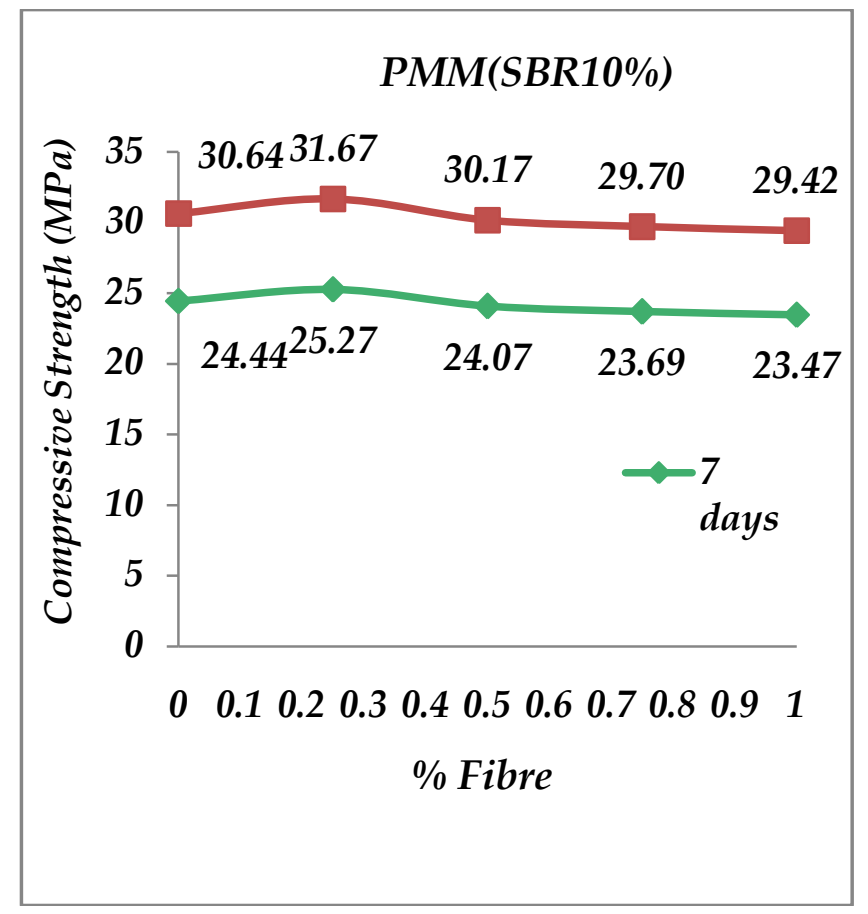

Fig.1 Variation in compressive strength with various $\%$ of fibre in PMM (SBR 10\%)

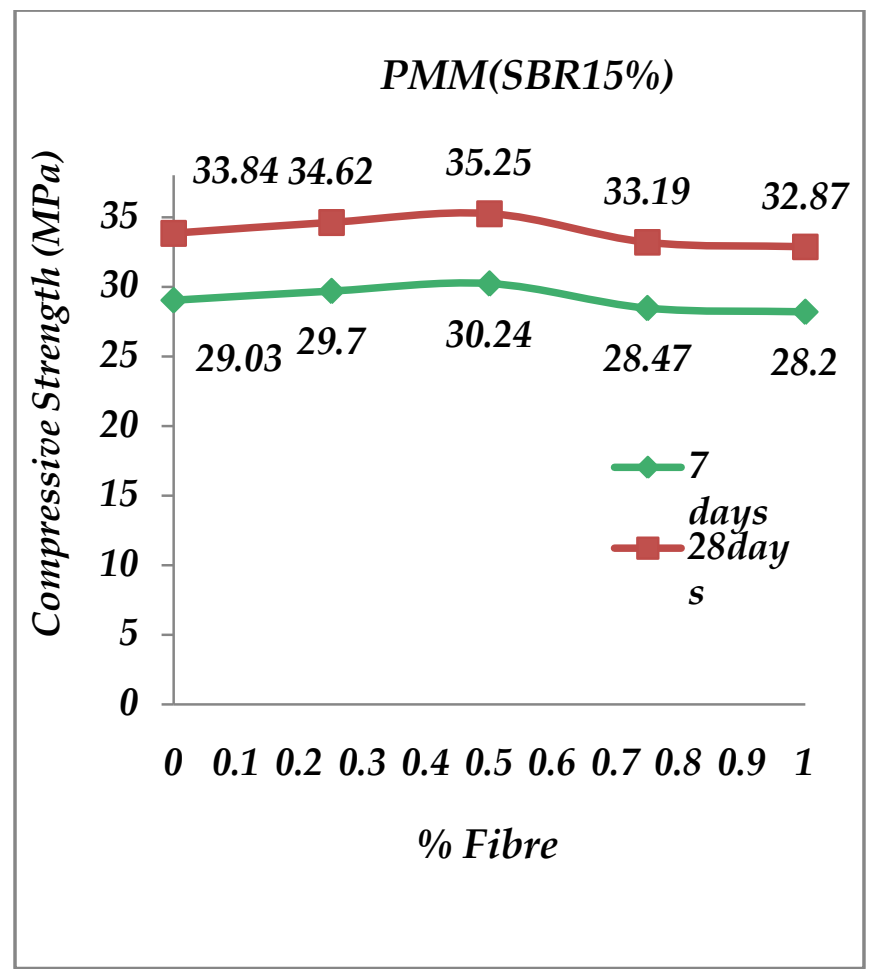

Fig.2 Variation in compressive strength with various $\%$ of fibre in PMM (SBR 15\%)

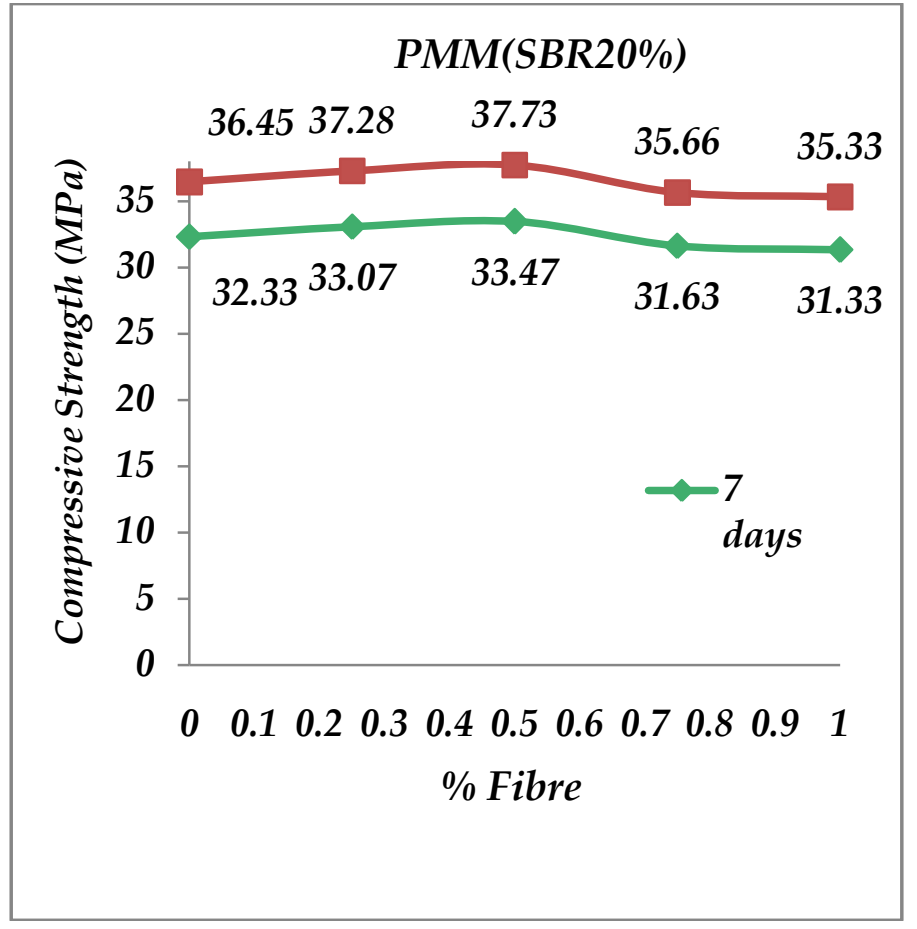

Fig.3 Variation in compressive strength with various \% of fibre in PMM (SBR 20\%)

\section{DISCUSSION ON TEST RESULTS:}

1. It is found that Compressive strength about $3 \%$ to 4 $\%$ increased at $0.25 \%$ polypropylene fibre by weight of cement, therefore dosage of optimum PPF suggested is $0.25 \%$ for PMM(SBR $10 \%)$.

2. It is also noted, for PMM (SBR $15 \%$ and $20 \%$ )Compressive strength about $4 \%$ increased at $0.50 \%$ polypropylene fibre by weight of cement, therefore dosage of optimum PPF suggested is 0.50 $\%$ for PMM(SBR $15 \%$ and $20 \%$ ).

3. Compressive strength also increased $10 \%-11 \%$ increased with change dosage of SBR $10 \%$ to SBR $15 \%$ by weight of cement in PMM.

4. We also found Increments noted in compressive strength by $15 \%-16 \%$ with change dosage of SBR $10 \%$ to SBR $20 \%$ by weight of cement in PMM.

\section{CONCLUSIONS}

$>$ Dosages of Polypropylene Fibre (PPF) recommend, for PMM SBR $10 \%$ (0.25\% PPF), SBR $15 \%$ and SBR $20 \%$ $(0.50 \%$ PPF $)$ to get optimum compressivestrength.

$>$ It is also concluded by increasing of dosage of SBR in PMM compressive strength increased $10-12 \%$ by dosage SBR $10 \%$ to SBR $15 \%$, but only $5-7 \%$ increment observed when switch to dosage of SBR $15 \%$ to SBR $20 \%$. 


\section{REFERENCES}

[1] A.A. shah , Y. Ribakov (2009), "Non-destructive evaluation of concrete in damaged and undamaged states materials and design" pp 3504-3511

[2] Alfarabisharif , Muhammad KalimurRahman,Ahmad, Al-Gahtani , Mohammed Hameeduddin (2006), "Behavior of patch repair of axially loaded reinforced concrete beams Cement \& Concrete Composites" 28, pp 734-741

[3] American Concrete Pavement Association (ACPA) (1989), "Guidelines for Partial-Depth Repair", Technical Bulletin TB-003P, American Concrete Pavement Association, Arlington Heights, Illinois.

[4] Austin, S.A. and Robins, P.J. (1993), "Development of Patch Test to Study Behavior of Shallow Concrete Patch Repairs", Magazine of Concrete Research, 45(164), pp $221-229$

[5] Baluch, M.H.Rahman, M.K., and ALGadhib,A.H.(2002), "Risk of Cracking and Delamination in Patch Repair", Journal of Materials in Civil Engineering, July- August, pp. 294-302

[6] Cable, J.K., Hart, J.M., and Ciha, T.J. (2001), "Thin Bonded Overlay Evaluation: Final Report", FHWA DTFH71-94-TBL-IH-37

[7] Cabrera, J.G. and Al-Hassan, A.S. (1997), "Performance Properties of Concrete Repair Materials", Construction and Building Materials, 11(5-6), pp 283290

[8] Carlo Pellegrino, Francesca da Porto, Claudio Modena (2009) "Rehabilitation of reinforced concrete axially loaded elements with polymer-modified" Cementitious mortar Construction and Building Materials $23 \mathrm{pp}$ 3129-3137

[9] Cusson, D. and Mailvaganam, n. (1996), "Durability of Repair Materials”, Concrete International, 18(3), pp 3438

[10] Czarnecki, 1., garbacz, a., lukowski, P., and CLIFTON, J.R. (1999). Polymer composites for Repairing of Portland Cement Concrete- Compatible project, NISTIR 6394, Building and Fire Research Laboratory, NIST, Gaithersburg, MD 20899

[11] Decter, M.H, and Keeley C. (1997), "Durability of concrete repair - Importance of Compatibility and low shrinkage", Construction and Building Materials, 11(56), pp 267-273

[12] D.G. Aggelis, T. Shiotani (2007). "Repair evaluation of concrete cracks using surface and through-transmission wave measurements". Cement \& Concrete Composites 29 pp 700-711

[13] Emberson, N.K., and Mays, G.C. (1990), "Significance of Property Mismatch in the Patch Repair of Structural Concrete Part 1: Properties of Repair Systems", Magazine of Concrete Research, 42(152), pp. 147-160
[14] Emmons, P.H. (1993), "Concrete Repair and Maintenance Illustrated”, Construction Publishers and Consultants, Kingston, MA, pp. 100-136

[15] Emmons, P.H.(2006). "Vision 2020 Repair/ Protection Council, Strategic Development Council", American Concrete Institute's Concrete Research and Education Foundation(Jul.1,2006)

[16] Emmons, P.H., Vaysburd, A.M., and Mcdonald, J.E. (1993). "A Rational Approach to durable concrete repairs", Concrete International, 15(9),pp 40-45

[17] Emmons, P.H., Vaysburd, A.M., and Mcdonald, J.E. (1994), "Concrete Repair in the Future Turn of The Century - Any Problem? ", 16(3), 42-48

[18] Federal Highway Administration (FHWA). (1985),FHWA "Pavement Rehabilitation Manual, FHWA-ED-88-025”, Federal Highway Administration, Washington, DC

[19] Federal Highway Administration (FHWA). (1985),FHWA "Pavement Rehabilitation Manual, FHWA-ED-88-025", Federal Highway Administration, Washington, DC

[20] GuangjingXiong, BaiyunLuo, Xiang Wu, Gengying Li, Liqiang Chen (2006) "Influence of silane coupling agent on quality of interfacial transition zone between concrete substrate and repair materials", Cement \& Concrete Composites 28 pp 97-101

[21] GuangjingXiong, Jinwei Liu, Gengying Li, HuicaiXie (2002) "A way for improving interfacial transition zone between concrete substrate and repair materials", Cement and Concrete Research 32 pp 1877-1881

[22] Kim Van Tittelboom, Nele De Belie A, Willem De Muynck A, Willy Verstraete (2010) "Use of bacteria to repair cracks in concrete", Cement and Concrete Research 40 pp 157-166

[23] Kosednar, J., and Mailvaganam, N.P. (2005) "Selection and use of Polymer-Based Materials in the Repair of Concrete Structures", Journal of Performance of Constructed Facilities, 19(3), pp 229-233

[24] Kreigh, J.D. (1976).“Arizona slant shear test”, ACI Journal, 73, pp 372-373.

[25] Lange, D.A., and Shin, H.C. (2001), "Early Age Stresses and Debonding in Bonded Concrete Overlays", Transportation Research Record 1778, pp. 174 - 181

[26] Li, S., Frantz, Geissert, D.G., Frantz, G.C., and Stephens, J.E. (1999), "Freeze-thaw Bond Durability of Rapid-Setting Concrete Repair Materials", ACI Materials Journal, 96(2), pp 242-249

[27] Mangat, P.S., and O'flaherty, F.J. (2000), “Influence of elastic modulus on stress redistribution and cracking in repair patches", Cement and Concrete Research, 30(2000), pp 125-136

[28] Mcdonald, J.E., Vaysburd, A.M., Emmons, P.H., Poston, R.W., and Kesner, K. (2002) "Selecting Durable repair Materials: Performance Criteria Summary", Concrete International, 24(1), pp 37-44 
[29] Ming-Gin Lee , Yung-Chih Wang , Chui-Te Chiu (2007) "A preliminary study of reactive powder concrete as a new repair material Construction and Building Materials" 21, pp 182-189

[30] Morgan, D.R. (1996), "Compatibility of Concrete Repair materials and Systems", Construction and Building Materials, 10(1), pp 57-67

[31] National Cooperative Highway Research Program (NCHRP) (1977), "Rapid Setting Materials for Patching of Concrete, NCHRP Synthesis of Highway Practice No. 45", Transportation Research Board, Washington, DC.

[32] PATEL, A.J., MOJAB, C.A.G., and ROMINE, A.R. (1999), "Materials and Procedures for Rapid Repair of Partial-Depth Spalls in Concrete Pavement, Manual of Practice for Concrete Pavement Repair", SHRP-H-349, Strategic Highway Research Program

[33] Parameswaran, Swati.(2004), "Investigating the role of Material Properties and their Variability in the Selection of Repair Materials", MS thesis, Purdue University

[34] Plum, D.R. (1990), "The behavior of Polymer Materials in Concrete Repair, and Factors Influencing Selection”, The Structural Engineer, 68(17), pp. 337-344

[35] Poston, R.W., Kesner, K., Mcdonald, J. E., Vaysburd, A.M., Emmons, P.H. (2000), "Selecting Durable Repair Materials: Performance Criteria - Laboratory Results", Concrete International, 22 (11), pp 21-29

[36] Poston, R.W., Kesner, K., Mcdonald, J. E., Vaysburd, A.M., Emmons, P.H. (2001), "Concrete Repair Material Performance - Laboratory Study", ACI Materials Journal, 98 (2), March/April 2001, pp. 137-147

[37] Poston,R.W.,Kesner,K.E.,Mcdonald,J.E., Vaysburd, A.M., and Emmons, P.H. (2001). "Concrete Repair Material Performance- Laboratory Study”, ACI Material Journal, 98 (4), pp 117-125

[38] Rizzo, E.M., and Sobelman, M.B. (1989), "Selection Criteria for Concrete Repair Materials", Concrete International, September 1989, pp. 46-49

[39] Robins, P.J., and Austin, S.A. (1995). "A unified failure envelope from the evaluation of concrete repair bond tests", Magazine of Concrete Research, 47 (170), pp 57-68.

[40] Shah, S.P, Weiss, W.J., and Yang, W. (1998), "Shrinkage Cracking - Can it be Prevented", Concrete International, 20(4), pp. 51-55

[41] "Standard specification for packaged, dry, rapidhardening cementitious materials for concrete repairs", ASTM C 928-00, Volume C 4.02, American Society for Testing and Materials, Philadelphia, PA (2004).

[42] "Standard Test Method for Bond Strength of Epoxy Resin Systems Used with Concrete", ASTM C 882-99, Vol. 4.02 American Society for Testing and Materials, Philadelphia, PA (2004).
[43] United Facilities Criteria, (2001), “O\&M- Concrete Repair”, UFC 3-270-04, US Army Corps of Engineers, pp 11-38

[44] Vaysburd, A.M., Emmons, P.H., Mailvaganam, N.P., Mcdonald, J.E., and Bissonnette, B.(2004). "Concrete Repair Technology - A revised approach is needed", Concrete International, 26(1), pp 59-65

[45] Vaysburd, A.M. Brown, C.D., Bissonnette, B., Emmons, P.H. (2004), "Realcrete" versus Labcrete", Concrete International, 26(2), pp 90-94

[46] Vaysburd, A.M., Emmons, P.H., Mc Donald, J.E., Poston, R.W., and Kesner, K.E. (2000). "Selecting Durable Repair materials: Performance criterial - Field Studies", Concrete International, 22(12), pp 39-45

[47] Waleed A. Thanoon, M.S. Jaafar , M. Razali A. Kadir, J. Noorzaei (2005) "Repair and structural performance of initially cracked reinforced concrete slabs". Construction and Building Materials 19, pp 595-603

[48] Wall, J.S., and Shrive, N.G. (1998)., "Factors affecting bond between new and old concrete", ACI Material Journal, 85 (2), pp 117-125.

[49] Weiss, W.J., Yang, W., and Shah, S.P. (1999), "Factors Influencing Durability and Early- Age Cracking in High-Strength Concrete Structures", ACI SP-189, High Performance Concrete: Research to Practice, Michigan, pp. 387-409

[50] Wilson, T.P, Smith, K.L, and Romine, A.R. (1999), "Materials and Procedures for Rapid Repair of PartialDepth Spalls in Concrete Pavements", SHRP-H-349, Strategic Highway Research Program, FHWA, Virginia

[51] Zia, P., Leming, L., And Ahmad, S.H. (1991), "High Performance Concretes: A State of the Art Report", SHRP-C/FR-91-103, Strategic Highway Research Program, Washington, DC 